\title{
Intensive care management of status epilepticus
}

\author{
Nidhi Gupta
}

\begin{abstract}
Status epilepticus (SE) is a life-threatening neurological emergency that requires prompt diagnosis and treatment. SE may be classified into convulsive and non-convulsive types, based on the presence of rhythmic jerking of the extremities. Clinically, tonic-clonic convulsive SE (CSE) is divided into four subsequent stages: Early, established, refractory and super-refractory. Initial elements of resuscitation include airway protection, haemodynamic resuscitation and seizure control. Further treatment should then be guided by the diagnostic workup. Rapid treatment of early SE is achieved with intravenous (IV) lorazepam or intramuscular midazolam. In established SE, IV antiepileptic drugs (AEDs) (phenytoin/fosphenytoin, valproate, levetiracetam, phenobarbital) are most commonly used, but there is no Class I evidence for choosing one over the other. Considered overall, cumulative data from the literature are consistent with valproate and levetiracetam, being a safe and effective therapeutic alternative to phenobarbital and phenytoin for treatment of established SE. Refractory SE (RSE) and super-RSE are treated with anaesthetic medications (propofol, midazolam, thiopental/pentobarbital, ketamine), non-anaesthetic drugs (lidocaine, magnesium, pyridoxine), AEDs (levetiracetam, lacosamide, topiramate, lacosamide, pregabalin, gabapentin) and other cause-directed treatments with low success rates. Potential non-pharmacologic interventions to be considered in super-RSE include hypothermia, electroconvulsive therapy, ketogenic diet, immunomodulatory treatments, emergency resective epilepsy surgery, cerebrospinal fluid drainage and vagal nerve or deep brain stimulation or transcranial magnetic stimulation. Diagnosis of non-CSE requires continuous electroencephalography and involves a high index of suspicion in all patients with an altered mental status of unclear cause or with a prolonged postictal state. Treatment options include addressing underlying causes and aggressive pharmacologic interventions with a benzodiazepine, phenytoin and valproate.
\end{abstract}

Key words: Antiepileptic drugs, neurointensive care unit, non-convulsive status epilepticus, refractory status epilepticus, status epilepticus, super-refractory status epilepticus

\section{INTRODUCTION}

Status epilepticus (SE) is one of the most frequent neurological emergencies that require prompt diagnosis

Department of Neuroanesthesia, Indraprastha Apollo Hospital, New Delhi, India

Address for correspondence:

Dr. Nidhi Gupta, Department of Neuroanesthesia,

Indraprastha Apollo Hospital, New Delhi - 110 076, India.

E-mail: drnidhisrivastava2@gmail.com

\begin{tabular}{|l|l|}
\hline \multicolumn{2}{|c|}{ Access this article online } \\
\hline Quick Response Code: & Website: \\
\hline & www.jnaccjournal.org \\
\cline { 2 - 2 } & \\
\hline
\end{tabular}

and treatment. Traditionally, it is defined as a single clinical seizure lasting for more than $30 \mathrm{~min}$ or repeated seizures over a period of more than $30 \mathrm{~min}$ without intervening recovery of consciousness ${ }^{[1]}$ However, most clinical and electrographic seizures last for $<5 \mathrm{~min}$ and seizures that last longer often do not stop spontaneously. ${ }^{[2]}$ Hence, for practical reasons, persistent clinical and/or electrographic seizure activity for $5 \mathrm{~min}$ or more should be considered SE and treated accordingly.

SE is associated with risks of decline in quality of life and cognition with 30-day mortality ranging from

This is an open access article distributed under the terms of the Creative Commons Attribution-NonCommercial-ShareAlike 3.0 License, which allows others to remix, tweak, and build upon the work non-commercially, as long as the author is credited and the new creations are licensed under the identical terms.

For reprints contact: reprints@medknow.com

How to cite this article: Gupta N. Intensive care management of status epilepticus. J Neuroanaesthesiol Crit Care 2016;3:83-95. 
9.4\% to $27 \%{ }^{[3,4]}$ Prolonged seizures are associated with higher mortality and worse clinical outcomes. Therefore, effective treatment should be initiated as soon as possible..$^{[-7]}$ This review addresses the diagnosis and Intensive Care Unit (ICU) management of both convulsive and non-convulsive SE (NCSE), in the wake of current available literature.

\section{CLASSIFICATION OF STATUS EPILEPTICUS}

SE should be classified as either CSE or NCSE. CSE is defined as convulsions that are associated with rhythmic jerking of the extremities while NCSE refers to electrographic seizure activity seen on electroencephalography (EEG) without clinically detectable seizure phenomenon. The term "refractory status epilepticus (RSE)' is applied when SE fails to respond to the first- and second-line anticonvulsants. It occurs in up to $44 \%$ of all patients with SE with a mortality rate of $16-23 \% .{ }^{[8]}$

Breakthrough seizures are defined as recurrence of SE during the treatment despite initial control, whereas withdrawal seizures are defined as recurrence of SE during or immediately after the tapering or withdrawal of the therapy; both result in the need for a change of therapy. In recent times, a new entity named super-RSE has been identified which describes a subtype of SE that continues or recurs $24 \mathrm{~h}$ or more after the onset of anaesthesia (third-line anticonvulsants) and includes scenarios in which SE recurs on reduction or withdrawal of anaesthesia. ${ }^{[9]}$ This is commonly seen in patients with severe acute brain insult and in whom SE develops suddenly with no overt cause (e.g., new-onset RSE syndrome).

\section{INTENSIVE CARE UNIT MANAGEMENT OF STATUS EPILEPTICUS}

The principal goal of treatment is to emergently stop both clinical and electrographic seizure activities. The treatment strategy includes:

- Simultaneous assessment and management of airway, breathing and circulation

- Emergent antiepileptic drug (AED) treatment to terminate seizure activity

- Screening for the underlying cause of SE

- Immediate treatment of life-threatening causes of SE (e.g., hypoglycaemia, hyponatraemia, meningitis, intracranial mass lesion)

- Preventing recurrence of seizure.

All patients should undergo a comprehensive initial workup with special investigations as per the clinical situation. A detailed neurological evaluation including a description of on-going convulsions, automatisms, focal deficits, pupillary changes and level of arousal is also useful. Bedside measures include insertion of two large-bore intravenous (IV) cannulas and oxygen supplementation. Airway protection may be facilitated by careful non-invasive methods initially, but early intubation is advisable if continuous IV AEDs are necessary. Vasopressor support and fluid resuscitation are required to maintain euvolaemia and avoid hypotension (treatment goals: keep systolic blood pressure $>90 \mathrm{mmHg}$ or mean blood pressure $>70 \mathrm{mmHg}$ ).

\section{Diagnostic workup}

The steps included in the diagnostic workup should be completed as soon as possible and occur simultaneously and in parallel with treatment. Most clinical studies emphasise thatSE aetiology remains the main determinant of outcome. ${ }^{[10,11]}$ Hence, the aetiology of SE should be diagnosed and treated as soon as possible [Table 1]. The diagnostic workup includes:

- Physical examination

- Finger-stick glucose - if hypoglycaemic, immediately administer $50 \mathrm{ml}$ of $50 \%$ dextrose in adults or $2 \mathrm{ml} / \mathrm{kg}$ of $25 \%$ dextrose to children

- Blood analysis for blood glucose, complete blood count, basic metabolic panel, calcium (total and ionised), magnesium and AED levels for specific medications, such as phenytoin/fosphenytoin, valproate and carbamazepine

- Urgent non-contrast computed tomography (CT) imaging of the head (once the seizure has ceased), especially useful in the evaluation of first seizure/SE or if the clinical setting suggests central nervous system (CNS) infections or a mass lesion.

- An early EEG - important in patients with persistent altered mental status and in those who may be difficult to diagnosis clinically, such as those in NCSE, pharmacologically induced coma or in patients who have received a paralytic agent

- Chest radiograph to exclude aspiration pneumonia

- Liver function tests, coagulation profile, arterial blood gas, an electrocardiogram and cardiac injury markers (serial troponins) depending on the patient's history and physical examination.

Patients with predisposing factors to metabolic derangements (e.g., renal failure, malignancy, malnutrition or those on diuretics) should, in general, receive a comprehensive metabolic evaluation. Thiamine (100 mg IV) should always be administered before or concurrent with glucose in patients suspected of alcohol abuse or impaired nutrition (conditions such as anorexia, bariatric surgery, dialysis, hyperemesis gravidarum).

An AED level should be checked in patients currently on treatment with AEDs and history obtained regarding 


\section{Table 1: Potential underlying aetiology of} status epilepticus

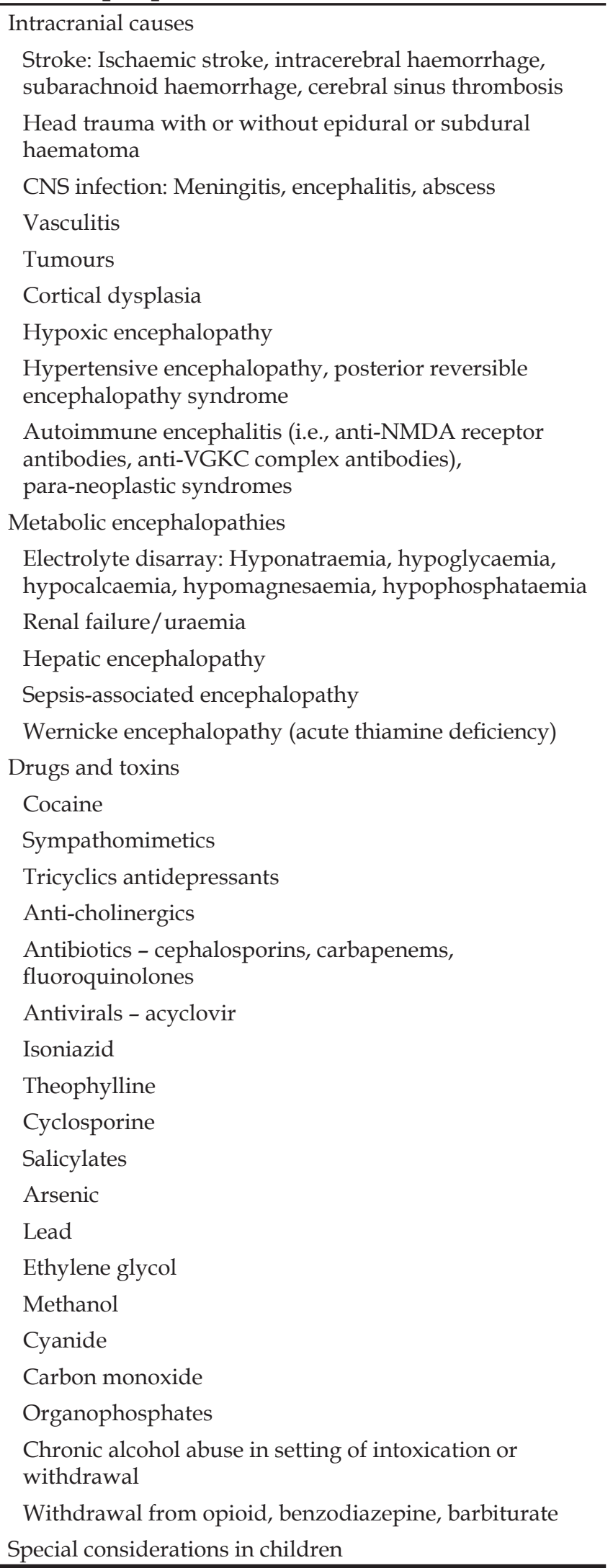

Contd...
Table 1: Contd...

Prolonged febrile seizures (most frequent cause of SE in children)

Inborn errors of metabolism

Defects in gluconeogenesis

Fatty acid oxidation disorders

Amino acid disorders

Organic acidaemiae

Urea cycle disorders

Carbohydrate disorders

Mitochondrial disorders

Peroxisomal disorders

Lysosomal storage disorders

Purine and pyrimidine disorders

Metal metabolism defects

Porphyrias

CNS: Central nervous system, NMDA: N-methyl-D-aspartate, VGKC:

Voltage-gated potassium channel, SE: Status epilepticus

compliance. Lumbar puncture (LP) should be performed for cerebrospinal fluid (CSF) examination in febrile patients and when there is suspicion of CNS infection or subarachnoid haemorrhage, preferably after obtaining the CT scan. Empirical treatment with antibiotics or antivirals should be started until the results from LP and imaging ancillary testing are available. Brain magnetic resonance imaging is more sensitive than CT in detecting subtle alterations of brain structures and is often preferred by neurologists for evaluating the first-time seizure.

If still there is no clear aetiology for SE, patient should be evaluated for toxins (blood and urine samples saved during initial workup) and inborn errors of metabolism or genetic abnormalities, especially if there is a family history. Comprehensive toxicology panel includes drugs/toxins that frequently cause seizures (i.e., isoniazid, tricyclic antidepressants, theophylline, cocaine, sympathomimetics, alcohol, organophosphates, cyclosporine and antibiotics such as quinolones, third-generation cephalosporins, cefepime and carbapenem), especially in patients with impaired renal or hepatic functions. The possibility of a psychogenic condition as the cause of epilepsy should also be ruled out carefully.

\section{MEDICAL MANAGEMENT OF STATUS EPILEPTICUS}

Definitive control of SE should be established within 60 min of onset. All patients presenting with SE will need emergent initial AED therapy (i.e., first line) and urgent control AED therapy (i.e., second line) in 
addition to AED maintenance therapy, even if SE is immediately controlled. Therapy for RSE (i.e., third and fourth line) is reserved for those failing the first two AEDs administered. The drugs used during different stages of management of SE along with their dosing and advantages and disadvantages are summarised in Tables 2 and 3.
When possible, the aetiology of SE should be treated promptly. SE known to result from toxins should preferentially be treated with specific antidotes. In a small percentage of treatable disorders such as herpes simplex encephalitis, cerebral venous sinus thrombosis and pyogenic infection, treatment of primary disorder may improve the outcome.

Table 2: Drug dosing in early and established status epilepticus

\begin{tabular}{|c|c|c|c|c|}
\hline Drug & Initial dosing & $\begin{array}{l}\text { Administration rates } \\
\text { and alternative dosing } \\
\text { recommendations }\end{array}$ & Advantages & Disadvantages \\
\hline Lorazepam & $\begin{array}{l}0.1 \mathrm{mg} / \mathrm{kg} \mathrm{IV} \\
\text { up to } \\
4 \mathrm{mg} / \text { dose, } \\
\text { may repeat in } \\
5-10 \mathrm{~min}\end{array}$ & $\mathrm{Up}$ to $2 \mathrm{mg} / \mathrm{min} \mathrm{IVP}$ & $\begin{array}{l}\text { Internationally } \\
\text { recommended } \\
\text { benzodiazepine for } \\
\text { treatment and prevention } \\
\text { of SE } \\
\text { Longer half-life }(12 \mathrm{~h}) \\
\text { Side effects are less than } \\
\text { diazepam and midazolam }\end{array}$ & $\begin{array}{l}\text { Less lipophilic than diazepam } \\
\text { and midazolam with a longer } \\
\text { onset of action } \\
\text { IV contains propylene glycol, not } \\
\text { suitable as a continuous infusion } \\
\text { Short shelf life outside of } \\
\text { refrigeration } \\
\text { Tolerance can develop early with } \\
\text { repeated use } \\
\text { Hypotension, respiratory } \\
\text { depression }\end{array}$ \\
\hline Midazolam & $\begin{array}{l}0.2 \mathrm{mg} / \mathrm{kg} \mathrm{IM} \\
\text { up to maximum } \\
\text { of } 10 \mathrm{mg}\end{array}$ & $\begin{array}{l}\text { Paediatrics: } 10 \mathrm{mg} \text { IM } \\
(>40 \mathrm{~kg}) ; 5 \mathrm{mg} \mathrm{IM} \\
(13-40 \mathrm{~kg}) ; 0.2 \mathrm{mg} / \mathrm{kg} \mathrm{IN} ; \\
0.5 \mathrm{mg} / \mathrm{kg} \text { buccal }\end{array}$ & $\begin{array}{l}\text { Active metabolite, highly } \\
\text { lipophilic agent, rapid } \\
\text { entry into CNS with rapid } \\
\text { control of SE } \\
\text { Renal elimination, rapid } \\
\text { redistribution (short } \\
\text { duration) - avoid excessive } \\
\text { sedation } \\
\text { Does not contain } \\
\text { propylene glycol - avoids } \\
\text { metabolic acidosis } \\
\text { associated with it } \\
\text { Only benzodiazepine with } \\
\text { pharmacokinetic properties } \\
\text { suitable for prolonged } \\
\text { infusion without } \\
\text { accumulation } \\
\text { Multiple routes of } \\
\text { administration }\end{array}$ & $\begin{array}{l}\text { Short half-life requiring } \\
\text { a continuous infusion } \\
\text { Risk of hepatic and renal } \\
\text { impairment } \\
\text { Hypotension, cardio-respiratory } \\
\text { depression }\end{array}$ \\
\hline Diazepam & $\begin{array}{l}0.15 \mathrm{mg} / \mathrm{kg} \mathrm{IV} \\
\text { up to } \\
10 \mathrm{mg} / \text { dose, } \\
\text { may repeat in } \\
5 \text { min }\end{array}$ & $\begin{array}{l}\text { Up to } 5 \mathrm{mg} / \mathrm{min} \text { IVP } \\
\text { Paediatrics: } 2-5 \text { years, } \\
0.5 \mathrm{mg} / \mathrm{kg} \text { PR; } 6-11 \text { years, } \\
0.3 \mathrm{mg} / \mathrm{kg} \text { PR; >12 years, } \\
0.2 \mathrm{mg} / \mathrm{kg} \text { PR }\end{array}$ & $\begin{array}{l}\text { Active metabolite } \\
\text { Acute antiepileptic effect }\end{array}$ & $\begin{array}{l}\text { Rapid redistribution - undergoes } \\
\text { accumulation into peripheral } \\
\text { compartment } \\
\text { CNS concentrations fall } \\
\text { rapidly - short duration of action, } \\
\text { higher reoccurrence of seizure } \\
\text { IV contains propylene glycol - } \\
\text { accumulation causes toxicity } \\
\text { Hypotension, respiratory } \\
\text { depression } \\
\text { PR route results in delayed, lower } \\
\text { and erratic absorption - no longer } \\
\text { recommended }\end{array}$ \\
\hline
\end{tabular}


Table 2: Contd...

\begin{tabular}{|c|c|c|c|c|}
\hline Drug & Initial dosing & $\begin{array}{l}\text { Administration rates } \\
\text { and alternative dosing } \\
\text { recommendations }\end{array}$ & Advantages & Disadvantages \\
\hline Phenytoin & $\begin{array}{l}20 \mathrm{mg} / \mathrm{kg} \mathrm{IV} \text {, may } \\
\text { give an additional } \\
5-10 \mathrm{mg} / \mathrm{kg} \\
\text { Loading dose } \\
\text { should not be } \\
\text { adjusted for } \\
\text { renal or hepatic } \\
\text { insufficiency }\end{array}$ & $\begin{array}{l}\text { Up to } 50 \mathrm{mg} / \mathrm{min} \mathrm{IV} \text {; may } \\
\text { give additional dose } 10 \mathrm{~min} \\
\text { after loading infusion }\end{array}$ & $\begin{array}{l}\text { One of the most widely } \\
\text { used AED } \\
\text { Lack of sedation } \\
\text { Easy switch to oral therapy } \\
\text { once SE is terminated }\end{array}$ & $\begin{array}{l}\text { Only compatible in saline } \\
\text { Prolonged administration rate } \\
(50 \mathrm{mg} / \mathrm{min} \text { [ } 25 \mathrm{mg} / \mathrm{min} \text { in } \\
\text { children, elderly patients and } \\
\text { those with co-morbidities]), in } \\
\text { no <30 min } \\
\text { Delayed onset of action } \\
\text { Hypotension and cardiac } \\
\text { arrhythmias may occur at high } \\
\text { infusion rates } \\
\text { IV contains polypropylene glycol } \\
\text { - may result in local irritation, } \\
\text { thrombophlebitis, compartment } \\
\text { syndrome, and 'purple glove } \\
\text { syndrome', as well as tissue } \\
\text { necrosis with extravasation }\end{array}$ \\
\hline Fosphenytoin & $\begin{array}{l}20 \mathrm{mg} \mathrm{PE} / \mathrm{kg} \\
\mathrm{IV}, \text { may give } \\
\text { additional } \\
5 \mathrm{mg} / \mathrm{kg}\end{array}$ & $\begin{array}{l}\text { Up to } 150 \mathrm{mg} \text { PE/min; } \\
\text { may give additional dose } \\
10 \text { min after loading } \\
\text { infusion } \\
\text { Paediatrics: Up to } \\
3 \mathrm{mg} / \mathrm{kg} / \mathrm{min}\end{array}$ & $\begin{array}{l}\text { Water-soluble prodrug that } \\
\text { is converted to phenytoin } \\
\text { by plasma esterases } \\
\text { Compatible in saline, } \\
\text { dextrose, and lactated } \\
\text { ringers solutions } \\
\text { Faster administration } \\
\text { rate (100-150 mg/min) as } \\
\text { compared with phenytoin } \\
\text { Less incidence of } \\
\text { thrombophlebitis than } \\
\text { phenytoin }\end{array}$ & $\begin{array}{l}\text { Maximal plasma concentrations } \\
\text { achieved are approximately } 15 \% \\
\text { lower than with phenytoin } \\
\text { Delayed onset of action similar } \\
\text { to phenytoin because of the } \\
\text { 15-min time to conversion from } \\
\text { fosphenytoin } \\
\text { Hypotension, arrhythmias }\end{array}$ \\
\hline Phenobarbital & $\begin{array}{l}20 \mathrm{mg} / \mathrm{kg} \mathrm{IV} \text {, may } \\
\text { give an additional } \\
5-10 \mathrm{mg} / \mathrm{kg} \\
\text { For RSE: } \\
5-15 \mathrm{mg} / \mathrm{kg} \text {, may } \\
\text { give additional } \\
5-10 \mathrm{mg} / \mathrm{kg} \text {; } \\
\text { administer at an } \\
\text { infusion rate } \\
\leq 50 \mathrm{mg} / \mathrm{min}\end{array}$ & $\begin{array}{l}50-100 \mathrm{mg} / \mathrm{min} \mathrm{IV} \text {, may } \\
\text { give additional dose } \\
10 \mathrm{~min} \text { after loading } \\
\text { infusion } \\
\text { For RSE: } 0.5-5 \mathrm{mg} / \mathrm{kg} / \mathrm{h} \mathrm{CI} \\
\text { Breakthrough SE: } 5 \mathrm{mg} / \mathrm{kg} \\
\text { bolus, increase CI rate by } \\
0.5-1 \mathrm{mg} / \mathrm{kg} / \mathrm{h} \text { every } 12 \mathrm{~h}\end{array}$ & $\begin{array}{l}\text { Widely used for neonatal } \\
\text { and childhood seizures }\end{array}$ & $\begin{array}{l}\text { IV contains propylene glycol } \\
\text { Sedation, hypotension, } \\
\text { respiratory depression }\end{array}$ \\
\hline $\begin{array}{l}\text { Valproate } \\
\text { sodium }\end{array}$ & $\begin{array}{l}20-40 \mathrm{mg} / \mathrm{kg} \\
\mathrm{IV}, \text { may give } \\
\text { an additional } \\
20 \mathrm{mg} / \mathrm{kg}\end{array}$ & $\begin{array}{l}3-6 \mathrm{mg} / \mathrm{kg} / \mathrm{min} \text {, may give } \\
\text { additional dose } 10 \mathrm{~min} \\
\text { after loading infusion } \\
\text { Paediatrics: } \\
1.5-3 \mathrm{mg} / \mathrm{kg} / \mathrm{min}\end{array}$ & $\begin{array}{l}\text { Less cardiopulmonary side } \\
\text { effects than phenytoin }\end{array}$ & $\begin{array}{l}\text { Not recommended in children } \\
\text { under the age of } 2 \text { due to its } \\
\text { association with fatal hepatotoxicity } \\
\text { Should not be given to patients } \\
\text { with mitochondrial disease or } \\
\text { severe liver disease } \\
\text { Hyperammonaemia, } \\
\text { pancreatitis thrombocytopenia, } \\
\text { hepatotoxicity }\end{array}$ \\
\hline Levetiracetam & $\begin{array}{l}\text { 1000-3000 mg IV } \\
\text { Pediatrics: } \\
\text { 20-60 mg/kg IV }\end{array}$ & $2-5 \mathrm{mg} / \mathrm{kg} / \mathrm{min} \mathrm{IV}$ & $\begin{array}{l}\text { Broad spectrum AED } \\
\text { Well tolerated } \\
\text { Minimal drug interactions } \\
\text { Not hepatically } \\
\text { metabolised } \\
\text { Very low rate of adverse } \\
\text { effects }\end{array}$ & $\begin{array}{l}\text { Somnolence and sedation } \\
\text { Rarely agitation and } \\
\text { thrombocytopenia }\end{array}$ \\
\hline
\end{tabular}

IV: Intravenous, IVP: Intravenous push, SE: Status epilepticus, IM: Intramuscular, IN: Intranasal, CNS: Central nervous system, PR: Per-rectal,

AED: Antiepileptic drug, PE: Phenytoin equivalent, RSE: Refractory status epilepticus, Cl: Continuous infusion 
Table 3: Drug dosing in refractory and super-refractory status epilepticus

\begin{tabular}{|c|c|c|c|c|}
\hline Drug & $\begin{array}{l}\text { Initial } \\
\text { dosing }\end{array}$ & $\begin{array}{l}\text { Continuous } \\
\text { infusion dosing } \\
\text { recommendations- } \\
\text { titrated to EEG }\end{array}$ & Advantages & Disadvantages \\
\hline Midazolam & $\begin{array}{l}0.2 \mathrm{mg} / \mathrm{kg} \mathrm{IV} \text {; } \\
\text { administer at } \\
\text { an infusion } \\
\text { rate of } \\
2 \mathrm{mg} / \mathrm{min}\end{array}$ & $\begin{array}{l}0.05-2 \mathrm{mg} / \mathrm{kg} / \mathrm{h} \mathrm{CI} \\
\text { Breakthrough } \\
\text { SE: } 0.1-0.2 \mathrm{mg} / \mathrm{kg} \\
\text { bolus, increase } \\
\mathrm{CI} \text { rate by } \\
0.05-0.1 \mathrm{mg} / \mathrm{kg} / \mathrm{h} \\
\text { every } 3-4 \mathrm{~h}\end{array}$ & $\begin{array}{l}\text { First-line therapy in most } \\
\text { cases } \\
\text { Only benzodiazepine } \\
\text { with pharmacokinetic } \\
\text { properties suitable for } \\
\text { prolonged infusion } \\
\text { without accumulation }\end{array}$ & $\begin{array}{l}\text { May be less effective than other } \\
\text { anaesthetics } \\
\text { Tachyphylaxis occurs after } \\
\text { prolonged use } \\
\text { Risk of tolerance and breakthrough } \\
\text { seizures (probably overestimated) } \\
\text { Avoid in hepatic or renal disease, } \\
\text { myasthenia gravis, porphyria } \\
\text { Hypotension, cardio-respiratory } \\
\text { depression }\end{array}$ \\
\hline $\begin{array}{l}\text { Thiopental/ } \\
\text { pentobarbital }\end{array}$ & $\begin{array}{l}\text { Thiopental: } \\
2-7 \mathrm{mg} / \mathrm{kg} \text {, } \\
\text { administer at } \\
\text { an infusion } \\
\text { rate } \\
\leq 50 \mathrm{mg} / \mathrm{min} \\
\text { Pentobarbital: } \\
5-15 \mathrm{mg} / \mathrm{kg} \text {, } \\
\text { may give } \\
\text { additional } \\
5-10 \mathrm{mg} / \mathrm{kg} \text {; } \\
\text { administer at } \\
\text { an infusion } \\
\text { rate } \\
\leq 50 \mathrm{mg} / \mathrm{min}\end{array}$ & $\begin{array}{l}\text { Thiopental: } \\
0.5-5 \mathrm{mg} / \mathrm{kg} / \mathrm{h} \text { CI } \\
\text { Breakthrough } \\
\text { SE: } 1-2 \mathrm{mg} / \mathrm{kg} \text { bolus, } \\
\text { increase CI rate by } \\
0.5-1 \mathrm{mg} / \mathrm{kg} / \mathrm{h} \text { every } \\
12 \mathrm{~h} \\
\text { Pentobarbital: } \\
0.5-5 \mathrm{mg} / \mathrm{kg} / \mathrm{h} \text { CI } \\
\text { Breakthrough } \\
\text { SE: } 5 \mathrm{mg} / \mathrm{kg} \text { bolus, } \\
\text { increase CI rate by } \\
0.5-1 \mathrm{mg} / \mathrm{kg} / \mathrm{h} \text { every } \\
12 \mathrm{~h}\end{array}$ & $\begin{array}{l}\text { First-line therapy in } \\
\text { severe cases } \\
\text { Strong antiepileptic action } \\
\text { Long clinical experience } \\
\text { Tendency to lower core } \\
\text { temperature } \\
\text { Theoretical } \\
\text { neuroprotective effects }\end{array}$ & $\begin{array}{l}\text { Very long half-life }(15-50 \mathrm{~h}) \\
\text { Requires mechanical ventilation } \\
\text { Hypotension, cardio-respiratory } \\
\text { depression, paralytic ileus } \\
\text { Avoid in hepatic disease, } \\
\text { myasthenia gravis, porphyria, } \\
\text { severe haemorrhage or burns, } \\
\text { cardiovascular disease, } \\
\text { adrenocortical insufficiency } \\
\text { Severe immunosuppression with } \\
\text { infections in the compromised } \\
\text { patient } \\
\text { At high doses, complete loss } \\
\text { of neurological function } \\
\text { Blood dyscrasias, and allergic } \\
\text { reactions ranging from angioedema } \\
\text { to Stevens-Johnson syndrome with } \\
\text { pentobarbital }\end{array}$ \\
\hline Propofol & $\begin{array}{l}\text { Start at } \\
20 \mathrm{mcg} / \mathrm{kg} / \\
\mathrm{min}, \\
\text { with } \\
1-2 \mathrm{mg} / \mathrm{kg} \\
\text { loading dose }\end{array}$ & $\begin{array}{l}30-200 \mathrm{mcg} / \mathrm{kg} / \mathrm{min} \\
\text { CI } \\
\text { Use caution when } \\
\text { administering high } \\
\text { doses } \\
\text { (>80 } \mathrm{mcg} / \mathrm{kg} / \mathrm{min}) \\
\text { for extended periods } \\
\text { of time (i.e., }>48 \mathrm{~h}) \\
\text { Paediatrics: Use } \\
\text { caution with doses } \\
>65 \text { mcg } / \mathrm{kg} / \mathrm{min} \text {; } \\
\text { contraindicated in } \\
\text { young children } \\
\text { Breakthrough SE: } \\
\text { Increase CI rate by } \\
5-10 \mathrm{mcg} / \mathrm{kg} / \mathrm{min} \\
\text { every } 5 \text { min or } \\
1 \text { mg/ } / \mathrm{kg} \text { bolus plus } \\
\text { CI titration }\end{array}$ & $\begin{array}{l}\text { First-line therapy } \\
\text { in complex cases } \\
\text { where ease of use } \\
\text { and pharmacokinetic } \\
\text { properties are important } \\
\text { Excellent pharmacokinetic } \\
\text { properties including very } \\
\text { rapid onset and recovery } \\
\text { even after prolonged } \\
\text { infusion allowing ease of } \\
\text { control of anaesthesia } \\
\text { No drug interactions } \\
\text { Less hypotension and } \\
\text { cardio-respiratory } \\
\text { depression than } \\
\text { barbiturate or midazolam } \\
\text { anaesthesia } \\
\text { Reduces ICP and brain } \\
\text { metabolic requirements } \\
\text { May have } \\
\text { immunomodulatory } \\
\text { effects }\end{array}$ & $\begin{array}{l}\text { Requires mechanical ventilation } \\
\text { Hypotension (especially with } \\
\text { loading dose in critically ill patients) } \\
\text { Propofol infusion syndrome in } \\
\text { patients treated with a high dose } \\
\text { starting at }>5 \mathrm{mg} / \mathrm{kg} / \mathrm{h} \text { or an } \\
\text { infusion time of } \geq 3 \text { days, especially } \\
\text { in children, critically ill adults, } \\
\text { patients with high fat and low } \\
\text { carbohydrate intake, concomitant } \\
\text { catecholamine infusion, and } \\
\text { concomitant corticosteroid use } \\
\text { Pain at the injection site } \\
\text { Rapid discontinuation may } \\
\text { precipitate withdrawal seizures } \\
\text { Difficulty in differentiating } \\
\text { drug-induced involuntary } \\
\text { movements and seizures } \\
\text { Caution with concurrent steroid or } \\
\text { catecholamine therapy } \\
\text { Must adjust daily caloric intake } \\
\text { (1.1 kcal/ml) }\end{array}$ \\
\hline
\end{tabular}


Table 3: Contd...

\begin{tabular}{|c|c|c|c|c|}
\hline Drug & $\begin{array}{l}\text { Initial } \\
\text { dosing }\end{array}$ & $\begin{array}{l}\text { Continuous } \\
\text { infusion dosing } \\
\text { recommendations- } \\
\text { titrated to EEG }\end{array}$ & Advantages & Disadvantages \\
\hline Ketamine & $1-3 \mathrm{mg} / \mathrm{kg}$ & $\mathrm{Up}$ to $5 \mathrm{mg} / \mathrm{kg} / \mathrm{h}$ & $\begin{array}{l}\text { Second-line therapy } \\
\text { especially where } \\
\text { hypotension or } \\
\text { cardiorespiratory } \\
\text { depression is problematic } \\
\text { Anti-glutaminergic action }\end{array}$ & $\begin{array}{l}\text { Very limited published experience } \\
\text { Increases blood pressure - caution } \\
\text { is warranted in patients with } \\
\text { elevated ICP, TBI, ocular injuries, } \\
\text { hypertension, chronic CHF, MI, and } \\
\text { tachyarrhythmias } \\
\text { Avoid in patients with history of } \\
\text { alcohol abuse } \\
\text { Possible neurotoxicity }\end{array}$ \\
\hline Lidocaine & $1-3 \mathrm{mg} / \mathrm{kg}$ & $\begin{array}{l}0.06 \mathrm{mg} / \mathrm{kg} / \mathrm{min}-\mathrm{up} \\
\text { to a maximum } \\
\text { infusion rate of } \\
5 \mathrm{mg} / \mathrm{min}\end{array}$ & $\begin{array}{l}\text { Rapid acting } \\
\text { anticonvulsant } \\
\text { Useful in the short term } \\
\text { management of SE } \\
\text { May be indicated in } \\
\text { patients in whom } \\
\text { respiratory depression is } \\
\text { undesirable }\end{array}$ & $\begin{array}{l}\text { Paradoxical pro-arrhythmic and, } \\
\text { rarely, pro-convulsant effects } \\
\text { Must be avoided in patients } \\
\text { with significant heart disease, in } \\
\text { particular, bradyarrhythmia or } \\
\text { conduction block and in patients } \\
\text { with liver dysfunction }\end{array}$ \\
\hline Topiramate & $\begin{array}{l}200-400 \mathrm{mg} \\
\text { orally in } \\
\text { adults } \\
\text { Paediatrics: } \\
5-10 \mathrm{mg} / \mathrm{kg} / \\
\text { day orally }\end{array}$ & $\begin{array}{l}300-1600 \mathrm{mg} / \text { day } \\
\text { orally (divided } \\
2-4 \text { times daily) } \\
\text { in adults } \\
\text { Paediatrics: } 5 \mathrm{mg} / \\
\mathrm{kg} / \text { day, if effective }\end{array}$ & $\begin{array}{l}\text { Broad-spectrum AED } \\
\text { with several modes of } \\
\text { action }\end{array}$ & $\begin{array}{l}\text { No IV formulation available } \\
\text { Metabolic acidosis, decreased } \\
\text { sweating and glaucoma }\end{array}$ \\
\hline Lacosamide & 200-400 mg IV & $\begin{array}{l}200 \mathrm{mg} \text { IV } \\
\text { over } 15 \text { min } \\
\text { No paediatric dosing } \\
\text { established }\end{array}$ & Minimal drug interactions & $\begin{array}{l}\text { Limited experience in treatment of SE } \\
\text { P-R interval prolongation in } \\
\text { electrocardiogram, AV-conduction } \\
\text { abnormalities, mild sedation, } \\
\text { hypotension }\end{array}$ \\
\hline $\begin{array}{l}\text { Magnesium } \\
\text { sulphate }\end{array}$ & $4 \mathrm{~g}$ bolus IV & $\begin{array}{l}\text { Continuous infusion } \\
\text { at a dose }(2-6 \mathrm{~g} / \mathrm{h}) \\
\text { that increases } \\
\text { the serum level } \\
\text { to } \approx 3.5 \mathrm{mmol} / \mathrm{L}\end{array}$ & $\begin{array}{l}\text { Proven efficacy in } \\
\text { managing eclamptic } \\
\text { seizures } \\
\text { Infusion is safe, without } \\
\text { significant adverse events }\end{array}$ & $\begin{array}{l}\text { No comparative study has been } \\
\text { conducted to assess its role in SE } \\
\text { management } \\
\text { Hypotension and P-R interval } \\
\text { prolongation are reported - caution } \\
\text { is advised when co-administered } \\
\text { with digoxin or calcium channel } \\
\text { blockers } \\
\text { Caution is advised when } \\
\text { co-administered with barbiturates } \\
\text { or benzodiazepines (due to a risk of } \\
\text { enhanced respiratory depression) } \\
\text { At high doses, the neuromuscular } \\
\text { blocking effects may mask } \\
\text { convulsive movements }\end{array}$ \\
\hline
\end{tabular}

IV: Intravenous, Cl: Continuous infusion, SE: Status epilepticus, ICP: Intracranial pressure, TBI: Traumatic brain injury, CHF: Congestive heart failure, MI: Myocardial infarction, AED: Antiepileptic drug, EEG: Electroencephalography, AV: Atrioventricular

\section{Rationale for using different drugs}

The rationale for using different drugs depends primarily on the changes occurring at cellular and synaptic level in the neurons as seizure activity progresses. In the initial stages, at cellular level, intrinsic defence mechanisms include enhanced release of the neurotransmitter gamma-aminobutyric acid (GABA), an inhibitory amino acid that serves to inhibit the actively discharging neurons. On a synaptic level, there is an initial up-regulation and expression of the $\mathrm{GABA}_{\mathrm{A}}$-receptor $\left(\mathrm{GABA}_{\mathrm{A}}-\mathrm{R}\right)$ $\delta 2$ subunit which is exquisitely sensitive to benzodiazepines. ${ }^{[12]}$ Benzodiazepines cause an increase in chloride permeability, which hyperpolarises and stabilises the membrane, rendering it less excitable. 
Failure to terminate seizures with benzodiazepines leads to the operational definition of early SE and requires use of AED as the second-line treatment. At this stage, the cellular mechanisms designed to abort seizures begin to fail. There is further expression of the

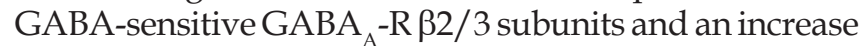
in GABA release from neuronal presynaptic vesicles which stimulates synaptophysin-L1 clathrin-dependent $\mathrm{GABA}_{\mathrm{A}}-\mathrm{R}$ internalisation. This causes a 20 -fold loss in benzodiazepine potency by $30 \mathrm{~min}$. Furthermore, there is an overall reduction in expression of 'benzodiazepine sensitive' GABA $A_{A}-R \delta 2$ subunit. Simultaneously, a slow and steady increase in the expression of excitatory $\mathrm{N}$-methyl-D-aspartate (NMDA) and $\alpha$-amino-3-hydrox y-5-methyl-4-isoxazolepropionic acid receptors occurs. These receptors are not sensitive to GABAergic AED or benzodiazepines leading to RSE.

There occurs an associated decrease of the inhibitory peptides (somatostatin, neuropeptide $Y$, dynorphin) and an increase in the pro-convulsant peptides (substance $\mathrm{P}$ and neurontin $\mathrm{B}$ ) which lasts for hours to days and are thought to contribute to self-sustaining seizures. ${ }^{[13]}$ Consequently, AED therapy should be continued even after cessation of clinical seizure activity. Continued seizures also result in blood-brain barrier dysfunction allowing the leakage of albumin into the CNS which acts as a pro-convulsant. Neuronal death at this stage is apparent as seen by an increase in neuron-specific enolase and decreased hippocampal neurons on autopsy. ${ }^{[14]}$

\section{Emergent initial therapy (first 5-10 min)}

A benzodiazepine (specifically intramuscular [IM] midazolam, IV lorazepam, or IV diazepam) is recommended as the initial therapy of choice given their demonstrated efficacy, safety and tolerability (Level A). ${ }^{[7]}$ If IV access is unavailable, benzodiazepines can be administered via IM, per-rectal, intranasal (IN) or buccal routes. Although IV phenobarbital is established as efficacious and well tolerated as initial therapy, its slower rate of administration compared with the three recommended benzodiazepines above positions it as an alternative initial therapy rather than a drug of the first choice.

Lorazepam is the agent of choice for emergent initial control of CSE in view of its longer intra-cerebral half-life (12 h) and a potentially longer anticonvulsive effect than other benzodiazepines. The first dose of lorazepam can be followed by a repeat dose 5-10 $\mathrm{min}$ after the first, which in turn is immediately followed by urgent control therapy with the second-line AED. The current evidence-based American Epilepsy Society guidelines for anticonvulsant therapy of children and adults with CSE demonstrate no significant difference in effectiveness between IV lorazepam and IV diazepam in adults or children with CSE (Level A). ${ }^{[7]}$ IV lorazepam is however more effective than IV phenytoin in stopping seizures lasting for at least $10 \mathrm{~min}$ (Level A). ${ }^{[7]}$

Midazolam is a highly lipophilic agent with rapid entry into the CNS (when given IV) and rapid offset. Thus, the initial fast high concentration helps to abort the seizure while avoiding excessive sustained sedation. Midazolam has significant advantages over lorazepam in out of hospital settings as it does not need refrigeration, and the administration of an IM drug is significantly easier and quicker than obtaining IV access for administration. In a recent prospective, randomised, pre-hospital trial, IM midazolam (10 mg in adults, $5 \mathrm{mg}$ in children) was found as effective at preventing SE as IV lorazepam (4 mg in adults, $2 \mathrm{mg}$ in children). ${ }^{[15]}$ Recent guidelines provide Level A evidence for the superior effectiveness of IM midazolam as compared to IV lorazepam in adults with CSE without established IV access. ${ }^{[7]}$ In children, IV lorazepam and IV diazepam are established as efficacious at stopping seizures lasting for at least $5 \mathrm{~min}$ (Level A) while rectal diazepam, IM midazolam, IN midazolam and buccal midazolam are probably effective (Level B). ${ }^{[7]}$

\section{Urgent control therapy (5-30 min)}

Fosphenytoin/phenytoin, valproate sodium, phenobarbital, levetiracetam or continuous infusion midazolam are preferred for urgent control of SE after failure of first-line therapy, referred to as established SE. In addition, AED therapy may be required in patients who respond to emergent initial therapy and have complete resolution of SE to attain therapeutic levels of an AED and continued dosing for maintenance therapy. Phenobarbitone is one of the oldest AEDs and is still widely used for neonatal and childhood seizures and for drug-resistant CSE and NCSE. ${ }^{[16]}$

Phenytoin has been one of the most widely used AEDs since its introduction and demonstrates good efficacy for $\mathrm{SE}$, especially in combination with benzodiazepines. ${ }^{[17]}$ However, the prolonged administration rate makes it difficult to achieve timely therapeutic drug levels in emergency situations. Phenytoin needs polypropylene glycol in an alkaline solution to prevent precipitation of the substance, which may result in severe side effects [Table 2]. Fosphenytoin partially avoids this issue and is better tolerated compared with phenytoin (Level B). ${ }^{[7]}$ When both are available, fosphenytoin is preferred based on tolerability; however, phenytoin is an acceptable alternative (Level B). ${ }^{[7]}$

Valproate sodium is worldwide the most often prescribed AED with a broad spectrum of efficacy against all seizure types. The chief advantage of sodium valproate over other AEDs is its safety and ease of administration. In 
recent reviews, IV sodium valproate was found to have a better tolerability than phenytoin in treatment of CSE, without any significant difference in terms of efficacy. ${ }^{[18,19]}$ Compared with diazepam, sodium valproate had a statistically significant lower time interval for control of RSE after having drugs, whereas there was no significant difference in cessation from status between IV sodium valproate and levetiracetam. ${ }^{[18]}$ Nonetheless, when using valproate, the possible induction of valproate encephalopathy and its differentiation from an on-going $\mathrm{SE}^{[20]}$ and rare occurrences of pancreatitis ${ }^{[21]}$ are problematic and should be kept in mind. According to American Epilepsy Society treatment guidelines for CSE, IV valproate has similar efficacy to IV phenytoin or continuous IV diazepam as the second therapy after failure of benzodiazepine (Level C). ${ }^{[7]}$

Levetiracetam is an efficacious and well-tolerated drug with a broad spectrum of efficacy. It has a low potential for interactions due to minimal hepatic metabolism and low plasma protein binding $(<10 \%)$. Levetiracetam has been found to have a relative effectiveness of $68.5 \%$ in benzodiazepine-resistant SE as compared with phenobarbital $73.6 \%$, phenytoin $50.2 \%$ and valproate $75.7 \% .{ }^{[22]}$ In a pilot study comparing its use with IV lorazepam in patients with early (Stage I) SE, both drugs were found equally effective in reaching clinical seizure cessation within $10 \mathrm{~min}$ of administration, but patients receiving lorazepam had significantly higher respiratory failure requiring artificial ventilation. ${ }^{[23]}$ This study suggested that levetiracetam is also effective in early-stage SE, where it might represent an alternative to lorazepam. However, because of only small clinical trials, insufficient data exist in adults about the efficacy of levetiracetam as either initial or second therapy. ${ }^{[7]}$

Currently, a high-class randomized controlled trial (RCT) comparing valproate, levetiracetam and phenytoin for established SE treatment trial is underway, and the first result can be expected in the next few years. ${ }^{[24]}$

In children, IV valproate has similar efficacy but better tolerability than IV phenobarbital (Level B) as the second therapy after failure of benzodiazepine. ${ }^{[7]}$ In paediatric patients (even in patients younger than 2 years), the adjunctive use of IV levetiracetam has been found effective and well tolerated. ${ }^{[25]}$ However, insufficient data exist in children regarding the efficacy of phenytoin or levetiracetam as the second therapy after failure of benzodiazepine.

\section{Treatment of refractory status epilepticus (30-60 min)}

At this stage after attempts to control the SE with bolus intermittent therapy fails, treatment recommendations are to use continuous infusion AEDs to suppress seizures. The use of valproate sodium, levetiracetam and phenytoin/fosphenytoin in intermittent boluses may also be considered if they have not previously been administered. AEDs most often recommended for use as a continuous infusion are midazolam, propofol and barbiturates (pentobarbital or thiopental). ${ }^{[2,27]}$ In addition to starting the continuous infusion, bolus doses of the AED chosen should be given initially and can be repeated for breakthrough SE.

At present, there is no Class I evidence regarding choice or duration of treatment in RSE and super-RSE due to a paucity of well-controlled RCTs. A systematic review of the treatment of 193 patients with RSE suggested that pentobarbital was more effective than midazolam or propofol in controlling clinical or electrophysiological seizures with a lower frequency of short-term treatment failure (8vs. $23 \%$ ) and breakthrough seizures ( $12 \%$ vs. $42 \%)$ but with more side effects such as hypotension (77\% vs. 34\%). ${ }^{[26]}$ Notably, pentobarbital was usually titrated to EEG background suppression using intermittent EEG monitoring, whereas midazolam and propofol were more often titrated to seizure suppression with continuous EEG monitoring. However, the three agents showed no differences in short-term case fatality which was between $40 \%$ and $50 \%$. In the only RCT comparing propofol with barbiturates for treatment of RSE, outcomes (mortality and functional outcome) and complications were similar between the groups except that the barbiturate group had longer times of mechanical ventilation. ${ }^{[28]}$ The trial was terminated after 3 years with only 24 patients recruited out of 150 required.

The increasing expression of NMDA receptors as SE progresses has prompted interest in the role of excitatory amino acid antagonists. Ketamine appears to be a relatively effective and safe anaesthetic, with a permanent control of up to $57 \%$ episodes of RSE observed in a retrospective multicentre study. ${ }^{[29]}$ Its use avoids the pitfalls and dangers of endotracheal intubation, which is known to worsen RSE prognosis. ${ }^{[30]}$ Ketamine, however, has the potential for adverse behavioural effects, such as the development of severe hypertension, psychosis and cerebral atrophy and hence, largely reserved as the second-line anaesthetic. ${ }^{[31]}$

Lidocaine is another possible alternative for the treatment of RSE. Lidocaine is used as antiarrhythmic; this property is attributed to the capacity to stabilise the cardiac membrane by blocking the fast voltage-gated sodium channels. Possibly, its antiepileptic activity may also to be related to sodium channel blockade. It has been found useful in SE with clustered or frequently repeated seizures and SE associated with benign infantile convulsion and convulsions with mild gastroenteritis. ${ }^{[32]}$ Despite having good clinical evidence in support of lidocaine for SE and RSE in the paediatric population, ${ }^{[33]}$ there is weak evidence to support its use in adults. ${ }^{[34]}$ 
Clobazam is a unique 1,5-benzodiazepine with improved safety (lack of sedating properties or issues with dependence) and tolerability as compared to other benzodiazepine. It has favourable pharmacokinetic properties such as rapid absorption and peak plasma levels within 1-4 h of administration, large volume of distribution and long half-life $(24 \mathrm{~h})$ and few significant drug interactions. Clobazam has been found useful as an effective and a promising option for add-on therapy in RSE, thus averting the need of anaesthetic drug infusions. ${ }^{[35]}$

Inhalational anaesthetics such as isoflurane and desflurane have been used for the treatment of RSE in small number of patients who do not respond to IV agents. ${ }^{[36]}$ However, complications such as severe hypotension, paralytic ileus and a high rate of recurrence after discontinuation are common. In addition, logistical problems in the ICU (i.e. need of a vaporiser and cart) are the main limitations of this form of therapy.

There is no agreement on the recommended EEG titration goal (burst suppression vs. seizure control) or duration of continuous infusion AED therapy for patients with RSE. Current guidelines recommend titration of propofol and barbiturate to EEG burst suppression, and midazolam to seizure suppression, maintained for $24-48 \mathrm{~h}$; with simultaneous initiation of the chronic AED, the patient will be treated with in future followed by gradual withdrawal of the continuous infusion AED. ${ }^{[5,6]}$ Seizures seen during discontinuation of continuous infusion AED typically will require restarting the infusion. Use of continuous infusion anaesthetic agents frequently requires assisted ventilation, invasive cardiovascular monitoring and use of vasopressors. Furthermore, patients receiving IV anaesthetic agents have higher proportion of infections and an increased risk of death compared with patients not receiving them. ${ }^{[3]}$

Recently, a multicentre RCT with the aim to identify the most effective dose of sodium valproate when used in combination with phenytoin for treatment of patients with RSE has been completed and results are expected soon. ${ }^{[38]}$

\section{Treatment of super-refractory status epilepticus}

The mainstay of therapy involves a combination of an AED and anaesthetics until a pattern of burst suppression is maintained on EEG. ${ }^{[10]}$ Drugs that have been used in the treatment of super-RSE include ketamine, magnesium, pyridoxine infusions and anti-epileptics including levetiracetam, topiramate, pregabalin, gabapentin and lacosamide. ${ }^{[10,39-43]}$

Other novel treatments in super-RSE, which have been described in the literature, include treatment with electroconvulsive therapy to stimulate extra GABA release, ${ }^{[44]}$ use of the ketogenic $\operatorname{diet}^{[45]}$ and induced hypothermia by endovascular cooling. ${ }^{[46]}$ Considering induced hypothermia, only mild hypothermia with target temperatures between $32^{\circ} \mathrm{C}$ and $35^{\circ} \mathrm{C}$ continued in the first instance for $24-48 \mathrm{~h}$ is found to be effective. ${ }^{[46]}$

It has been argued that some cases of cryptogenic RSE are caused by underlying occult immunologic diseases with antibodies (not yet identified) directed against neural elements or inflammatory conditions in whom standard treatment options do fail. ${ }^{[47]}$ Hence, a trial of immunotherapy is worthwhile as the second-line therapy in patients with super-RSE without a history of previous epilepsy and in whom no aetiology has been found. Initially, a trial of high-dose steroids $(1 \mathrm{~g}$ of IV prednisolone/day for 3 days followed by $1 \mathrm{mg} / \mathrm{kg} /$ day for $\approx 1$ week) is given. In case there is no clinical response within 2 days, either IV immunoglobulin (at a dose of $0.4 \mathrm{~g} / \mathrm{kg}$ over 5 days) or plasma exchange can be tried in addition. If there is a response, treatment is continued with long-term corticosteroids, repeated courses of IV immunoglobulin and later, other immunomodulatory agents such as cyclophosphamide or rituximab. ${ }^{[10]}$

Patients with catastrophic epilepsy including SE can benefit from emergency resective epilepsy surgery, even with incomplete resection of the epileptogenic lesion. ${ }^{[48]}$ Surgeries, such as hemispherectomy, corpus callosotomy and anterior temporal lobe resection, may be associated with delayed complications such as bleeding, haematoma formation and obstructive hydrocephalus; however, they may ultimately be the most effective measure in providing relief to patients with intractable epilepsy. ${ }^{[49]}$

CSF drainage may help as the last resort therapy, in severe super-RSE by removing inflammatory or other compounds from the CSF or, less likely, via changes of intracranial pressure dynamics. ${ }^{[50]}$ In relation to vagal nerve stimulation, deep brain stimulation and repetitive transcranial magnetic stimulation, there is no clear evidence of any efficacy from these therapies. ${ }^{[51]}$ They have all been tried with varying degrees of success in single cases or small case series. It remains unclear, however, which brain areas should be stimulated and the parameters that should be used.

\section{Treatment of non-convulsive status epilepticus}

NCSE is known to be a heterogeneous disorder with varied causes and several subtypes. It is estimated that up to $25 \%$ of all cases of SE are of the non-convulsive type. ${ }^{[52]}$ NCSE can either occur de novo or develop after a convulsive event, and it should be in the differential diagnosis of any patient with new-onset altered behaviour of undetermined cause. 
The two most commonly recognised types of NCSE are absence SE and complex partial SE The primary clinical manifestation of both types of NCSE is altered mental status, varying from mild confusion all the way to coma. It can be difficult differentiating these two types of NCSE based on clinical features alone. However, there is little bearing on emergency management in making the distinction. NCSE resulting in a coma must be differentiated from a convulsive seizure that has 'burnt out', a condition termed subtle generalised CSE or subtle SE (SSE). SSE is generally associated with significant CNS injury and unlike other types, carries a grave prognosis. ${ }^{[53]}$

NCSE can only be diagnosed and managed adequately using continuous EEG. ${ }^{[54]}$ To date, several different definitions and diagnostic criteria have been proposed to address and try to solve the diagnostic problems related to this condition. ${ }^{[5]}$ As the diagnosis of NCSE is electro-clinical, diagnostic criteria for this epileptic condition should take into account both clinical and EEG features. Evaluating only EEG features without considering clinical aspects may lead to serious consequences, such as misdiagnosis of NCSE and consequent aggressive (and potentially harmful) AED treatment. NCSE may be regarded as proven only if both EEG and clinical state improve with AED treatment.

Although the treatment for CSE is well established, there is no clear consensus for the treatment of NCSE. To date, there are no randomised, multicentre treatment trials for non-convulsive seizures (NCS) or NCSE. Hence, treatment recommendations for CSE are often extrapolated to NCS/NCSE despite lack of data confirming the appropriateness of this practice.

Currently, there is a trend for using non-sedative anticonvulsants for NCS and NCSE including phenytoin/fosphenytoin, lorazepam or levetiracetam, with slightly more use of levetiracetam for NCS than NCSE. ${ }^{[54]}$ In recent times, IV lacosamide has also been found to be effective and safe in this patient population as an add-on therapy, when standard therapy fails. ${ }^{[56]}$

\section{The multifaceted care of status epilepticus}

After seizure control is achieved, long-term, multifaceted care of SE patients involving every major organ may be needed in a dedicated neuro-ICU. Systemic manifestations of on-going seizure activity in SE include fever, acid-base imbalance, cardiopulmonary complications, irreversible cerebral injury, bowel ischaemia and acute non-oliguric renal failure. ${ }^{[57-60]}$

Common acid-base abnormalities include metabolic acidosis from excessive muscular activity, whereas respiratory acidosis may result from aspiration and decreased respiratory drive. Pulmonary complications including pneumonia (both health-acquired and ventilator-associated), pulmonary effusion, atelectasis, consolidation and neurogenic pulmonary oedema are also common, requiring mechanical ventilation, parenteral antibiotics and repeated bronchoscopies.

Cardiac arrhythmias including ventricular tachycardia/fibrillation, atrioventricular block, atrial fibrillation/flutter, sinus bradycardia and sinus tachycardia are common with more than two-thirds requiring cardiac intervention. ${ }^{[57]}$ Apical ballooning cardiomyopathy (i.e. Takotsubo cardiomyopathy) has been described after SE, representing the massive hyperadrenergic response during seizures and may be the cause of hypotension in RSE. ${ }^{[58]}$

Bowel ischaemia is a rare, life-threatening complication seen in patients with RSE. The possible aetiologies include RSE itself, systemic hypotension, vasopressor use, general anaesthesia (continuous barbiturate infusions), and abnormal cardiac function. ${ }^{[59]}$ Continuous seizures may cause muscle damage leading to acute non-oliguric renal failure from rhabdomyolysis and myoglobinuria thus, requiring early renal replacement therapy. ${ }^{[60]}$

Use of continuous infusion AEDs results in considerable side effects and frequently requires assisted ventilation and vasopressor therapy with predicted poor outcome and death. ${ }^{[61]}$ Systemic complications associated with prolonged use of anaesthetic drugs in RSE and super-RSE includes refractory hypotension, propofol infusion syndrome, propylene glycol toxicity with severe lactic acidosis (propylene glycol is a vehicle in lorazepam, barbiturates and etomidate), and possibly excitotoxic brain injury with inhalational anaesthetic isoflurane. ${ }^{[61-64]}$

Other systemic complications associated with prolonged mechanical ventilation and immobilised state include a high risk of pneumonia, sepsis, pseudomembranous colitis, adynamic ileus, urinary tract infections, skin lesions, decubitus ulcers, deep venous thrombosis and pulmonary embolism. The long-term outcome effects of therapeutic options available for refractory and super-refractory CSEs include death (35\%), severe neurological deficit $(13 \%)$, mild neurological deficit $(13 \%)$, undefined deficit $(4 \%)$ and recovery to baseline $(35 \%) \cdot{ }^{[39]}$

\section{CONCLUSION}

In patients with SE, the efficacy of treatment given and the associated morbidity and mortality is directly related to delays in starting definitive therapy. Currently, a few evidence-based guidelines are available for initial therapy of patients with early and established SE. However, there are very little empirical data to guide the choice 
of therapy in an evidence-based fashion in the setting of RSE, super-RSE and NCSE as classic RCTs satisfying contemporary standards are extremely challenging to perform. Hence, treatment modality is often based on expert opinion and available critical care resources. Further, RCTs are needed to identify appropriate monitoring and the most effective treatment modality in addition to clarifying the basic pathophysiological mechanisms of these emergencies.

\section{Financial support and sponsorship \\ Nil.}

\section{Conflicts of interest}

There are no conflicts of interest.

\section{REFERENCES}

1. Treatment of convulsive status epilepticus. Recommendations of the Epilepsy Foundation of America's Working Group on Status Epilepticus. JAMA 1993;270:854-9.

2. Jenssen S, Gracely EJ, Sperling MR. How long do most seizures last? A systematic comparison of seizures recorded in the epilepsy monitoring unit. Epilepsia 2006;47:1499-503.

3. Tomson T. Mortality in epilepsy. J Neurol 2000;247:15-21.

4. Meierkord $H$. The risk of epilepsy after status epilepticus in children and adults. Epilepsia 2007;48 Suppl 8:94-5.

5. Meierkord H, Boon P, Engelsen B, Göcke K, Shorvon S, Tinuper $\mathrm{P}$, et al. EFNS guideline on the management of status epilepticus in adults. Eur J Neurol 2010;17:348-55.

6. Brophy GM,Bell R,Claassen J,Alldredge B,Bleck TP, Glauser T, et al. Guidelines for the evaluation and management of status epilepticus. Neurocrit Care 2012;17:3-23.

7. Glauser T, Shinnar S, Gloss D, Alldredge B, Arya R, Bainbridge J, et al. Evidence-based guideline: Treatment of convulsive status epilepticus in children and adults: Report of the Guideline Committee of the American Epilepsy Society. Epilepsy Curr 2016;16:48-61.

8. Mayer SA, Claassen J, Lokin J, Mendelsohn F, Dennis LJ, Fitzsimmons BF. Refractory status epilepticus: Frequency, risk factors, and impact on outcome. Arch Neurol 2002;59:205-10.

9. Shorvon S, Ferlisi M. The treatment of super-refractory status epilepticus: A critical review of available therapies and a clinical treatment protocol. Brain 2011;134(Pt 10):2802-18.

10. Rossetti AO, Hurwitz S, Logroscino G, Bromfield EB.Prognosis of status epilepticus: Role of aetiology, age, and consciousness impairment at presentation. J Neurol Neurosurg Psychiatry 2006;77:611-5.

11. Sokic DV, Jankovic SM, Vojvodic NM, Ristic AJ. Etiology of a short-term mortality in the group of 750 patients with 920 episodes of status epilepticus within a period of 10 years (1988-1997). Seizure 2009;18:215-9.

12. Naylor DE, Liu H, Wasterlain CG. Trafficking of GABA (A) receptors, loss of inhibition, and a mechanism for pharmacoresistance in status epilepticus. J Neurosci 2005;25:7724-33.

13. Sperk G, Wieser R, Widmann R, Singer EA. Kainic acid induced seizures: Changes in somatostatin, substance $P$ and neurotensin. Neuroscience 1986;17:1117-26.

14. Sloviter RS. Status epilepticus-induced neuronal injury and network reorganization. Epilepsia 1999;40 Suppl 1:S34-9.

15. Silbergleit R, Durkalski V, Lowenstein D, Conwit R,Pancioli A, Palesch Y, et al. Intramuscular versus intravenous therapy for prehospital status epilepticus. N EnglJ Med 2012;366:591-600.

16. Brodie MJ, Kwan P. Current position of phenobarbital in epilepsy and its future. Epilepsia 2012;53 Suppl 8:40-6.

17. Treiman DM, Meyers PD, Walton NY, Collins JF, Colling C, Rowan AJ, et al. A comparison of four treatments for generalized convulsive status epilepticus. Veterans Affairs Status Epilepticus Cooperative Study Group. N Engl J Med 1998;339:792-8.

18. Liu X, Wu Y, Chen Z, Ma M, Su L. A systematic review of randomized controlled trials on the theraputic effect of intravenous sodium valproate in status epilepticus. Int J Neurosci 2012;122:277-83.

19. Brigo F, Storti M, Del Felice A, Fiaschi A, Bongiovanni LG. IV Valproate in generalized convulsive status epilepticus: A systematic review. Eur J Neurol 2012;19:1180-91.

20. Velioglu SK, Gazioglu S. Non-convulsive status epilepticus secondary to valproic acid-induced hyperammonemic encephalopathy. Acta Neurol Scand 2007;116:128-32.

21. Grosse P, Rüsch L, Schmitz B. Pancreatitis complicating treatment with intravenous valproic acid. J Neurol 2002;249:484-5.

22. Yasiry Z, Shorvon SD. The relative effectiveness of five antiepileptic drugs in treatment of benzodiazepine-resistant convulsive status epilepticus: A meta-analysis of published studies. Seizure 2014;23:167-74.

23. Misra UK, Kalita J, Maurya PK. Levetiracetam versus lorazepam in status epilepticus: A randomized, open labeled pilot study. J Neurol 2012;259:645-8.

24. Bleck T, Cock H, Chamberlain J, Cloyd J, Connor J, Elm J, et al. The established status epilepticus trial 2013. Epilepsia 2013;54 Suppl 6:89-92.

25. Kim JS, Lee JH, Ryu HW, Lim BC, Hwang H, Chae JH, et al. Effectiveness of intravenous levetiracetam as an adjunctive treatment in pediatric refractory status epilepticus. Pediatr Emerg Care 2014;30:525-8.

26. Claassen J, Hirsch LJ, Emerson RG, Mayer SA. Treatment of refractory status epilepticus with pentobarbital, propofol, or midazolam: A systematic review. Epilepsia 2002;43:146-53.

27. Prabhakar H, Bindra A, Singh GP, Kalaivani M. Propofol versus thiopental sodium for the treatment of refractory status epilepticus (Review). Evid Based Child Health 2013;8:1488-508.

28. Rossetti AO, Milligan TA, Vulliémoz S, Michaelides C, Bertschi M, Lee JW. A randomized trial for the treatment of refractory status epilepticus. Neurocrit Care 2011;14:4-10.

29. Gaspard N, Foreman B, Judd LM, Brenton JN, Nathan BR, McCoy BM, et al. Intravenous ketamine for the treatment of refractory status epilepticus: A retrospective multicenter study. Epilepsia 2013;54:1498-503.

30. Ilvento L, Rosati A,Marini C,L'Erario M,Mirabile L, Guerrini R. Ketamine in refractory convulsive status epilepticus in children avoids endotracheal intubation. Epilepsy Behav 2015;49:343-6.

31. Ubogu EE, Sagar SM, Lerner AJ, Maddux BN, Suarez JI, Werz MA. Ketamine for refractory status epilepticus: A case of possible ketamine-induced neurotoxicity. Epilepsy Behav 2003; 4:70-5.

32. Hattori H,Yamano T,Hayashi K,Osawa M,Kondo K,Aihara M, et al. Effectiveness of lidocaine infusion for status epilepticus in childhood: A retrospective multi-institutional study in Japan. Brain Dev 2008;30:504-12.

33. Zeiler FA, Zeiler KJ, Teitelbaum J, Gillman LM, West M, Kazina CJ. Lidocaine for status epilepticus in pediatrics. Can J Neurol Sci 2015;42:414-26.

34. Zeiler FA, Zeiler KJ, Kazina CJ, Teitelbaum J, Gillman LM, West M. Lidocaine for status epilepticus in adults. Seizure 2015;31:41-8.

35. Sivakumar S, Ibrahim M, Parker D Jr., Norris G, Shah A, Mohamed W. Clobazam: An effective add-on therapy in refractory status epilepticus. Epilepsia 2015;56:e83-9. 
36. Mirsattari SM, Sharpe MD, Young GB. Treatment of refractory status epilepticus with inhalational anesthetic agents isoflurane and desflurane. Arch Neurol 2004;61:1254-9.

37. Sutter R, Marsch S, Fuhr P, Kaplan PW, Rüiegg S. Anesthetic drugs in status epilepticus: Risk or rescue? A 6-year cohort study. Neurology 2014;82:656-64.

38. Refractory Status Epilepticus Treatment Study. Available from: https://www.clinicaltrials.gov/ct2/show/NCT01586208. [Last Accessed on 2016 Mar 12].

39. Ferlisi M, Shorvon S. The outcome of therapies in refractory and super-refractory convulsive status epilepticus and recommendations for therapy. Brain 2012;135(Pt 8):2314-28.

40. Visser NA, Braun KP, Leijten FS, van Nieuwenhuizen O, Wokke JH, van den Bergh WM. Magnesium treatment for patients with refractory status epilepticus due to POLG1-mutations. J Neurol 2011;258:218-22.

41. Yeghiazaryan NS, Zara F, Capovilla G, Brigati G, Falsaperla R, Striano P. Pyridoxine-dependent epilepsy: An under-recognised cause of intractable seizures. J Paediatr Child Health 2012;48:E113-5.

42. Hottinger A, Sutter R, Marsch S, Rüegg S. Topiramate as an adjunctive treatment in patients with refractory status epilepticus: An observational cohort study. CNS Drugs 2012;26:761-72.

43. Sutter R, Marsch S, Rüiegg S. Safety and efficacy of intravenous lacosamide for adjunctive treatment of refractory status epilepticus: A comparative cohort study. CNS Drugs 2013;27:321-9.

44. Lambrecq V,VillégaF, Marchal C, Michel V, Guehl D, Rotge JY, et al. Refractory status epilepticus: Electroconvulsive therapy as a possible therapeutic strategy. Seizure 2012;21:661-4.

45. Nam SH, Lee BL, Lee CG, Yu HJ, Joo EY, Lee J, et al. The role of ketogenic diet in the treatment of refractory status epilepticus. Epilepsia 2011;52:e181-4.

46. Corry JJ, Dhar R, Murphy T, Diringer MN. Hypothermia for refractory status epilepticus. Neurocrit Care 2008;9:189-97.

47. Vezzani A, Ruegg S. Immunity and inflammation in epilepsy: A mechanistic insights and therapeutic perspectives. Epilepsia 2011;52:1-53.

48. Winkler PA. Surgical treatment of status epilepticus: A palliative approach. Epilepsia 2013;54 Suppl 6:68-71.

49. Widjaja E, Li B, Schinkel CD, Puchalski Ritchie L, Weaver J, Snead OC, et al. Cost-effectiveness of pediatric epilepsy surgery compared to medical treatment in children with intractable epilepsy. Epilepsy Res 2011;94:61-8.
50. Köhrmann M, Huttner HB, Gotthardt D, Nagel S, Berger C, Schwab S. CSF-air-exchange for pharmacorefractory status epilepticus. J Neurol 2006;253:1100-1.

51. Walker MC. The potential of brain stimulation in status epilepticus. Epilepsia 2011;52 Suppl 8:61-3.

52. Dunne JW, Summers QA, Stewart-Wynne EG. Non-convulsive status epilepticus: A prospective study in an adult general hospital. Q J Med 1987;62:117-26.

53. DeLorenzo RJ, Waterhouse EJ, Towne AR, Boggs JG, Ko D, DeLorenzo GA, et al. Persistent nonconvulsive status epilepticus after the control of convulsive status epilepticus. Epilepsia 1998;39:833-40.

54. Abend NS, Dlugos DJ, Hahn CD, Hirsch LJ, Herman ST. Use of EEG monitoring and management of non-convulsive seizures in critically ill patients: A survey of neurologists 2010;12:382-9.

55. Brigo F. Nonconvulsive status epilepticus: The diagnostic dilemma. Neurol India 2013;61:3-6.

56. Koubeissi MZ, Mayor CL, Estephan B, Rashid S, Azar NJ. Efficacy and safety of intravenous lacosamide in refractory nonconvulsive status epilepticus. Acta Neurol Scand 2011;123:142-6.

57. Hocker S, Prasad A, Rabinstein AA. Cardiacinjury in refractory status epilepticus. Epilepsia 2013;54:518-22.

58. Stöllberger C, Wegner C, Finsterer J. Seizure-associated takotsubo cardiomyopathy. Epilepsia 2011;52:e160-7.

59. Rizek P, Ikeda KM, Mele T, Garcia B, Gofton TE. Bowel ischemia in refractory status epilepticus: Report of two cases and review of the literature. Neurocrit Care 2016;24:128-31.

60. Gupta P, Singh VP, Chatterjee S, Agarwal AK. Acute renal failure resulting from rhabdomyolysis following a seizure. Singapore Med J 2010;51:e79-80.

61. Kowalski RG, Ziai WC, Rees RN, Werner JK Jr., Kim G, Goodwin $\mathrm{H}$, et al. Third-line antiepileptic therapy and outcome in status epilepticus: The impact of vasopressor use and prolonged mechanical ventilation. Crit Care Med 2012;40:2677-84.

62. Diedrich DA, Brown DR. Analytic reviews: Propofol infusion syndrome in the ICU. J Intensive Care Med 2011;26:59-72.

63. Bledsoe KA, Kramer AH.Propylene glycol toxicity complicating use of barbiturate coma. Neurocrit Care 2008;9:122-4.

64. Fugate JE, Burns JD, Wijdicks EF, Warner DO, Jankowski CJ, Rabinstein AA. Prolonged high-dose isoflurane for refractory status epilepticus: Is it safe? Anesth Analg 2010;111:1520-4. 